\title{
Neonatal outcomes of pregnant women diagnosed with SARS-CoV-2: an integrative
}

\section{review}

\author{
Desfechos neonatais de gestantes com diagnóstico de SARS-CoV-2: uma revisão integrativa \\ Resultados neonatales de mujeres embarazadas diagnosticadas con SARS-CoV-2: una revisión \\ integradora
}

Received: 12/04/2020 | Reviewed: 12/10/2020 | Accept: 12/12/2020 | Published: 01/01/2021

João Victor Farias da Silva

ORCID: https://orcid.org/0000-0001-8800-5540

Federal University of Sergipe, Brazil

E-mail: joaovictorfarias15@gmail.com

Mônica Vilela Heimer

ORCID: https://orcid.org/0000-0003-3842-192X

University of Pernambuco, Brazil

E-mail: monica.vilelaheimer@gmail.com

Laura Mello Figueiredo

ORCID: https://orcid.org/0000-0002-8089-0933

University of Tiradentes, Brazil

E mail: lauramfigueiredo@hotmail.com

Daniela Maria Carvalho Pugliesi

ORCID: https://orcid.org/0000-0002-7854-0416

Federal University of Alagoas, Brazil

E mail: dpugliesi@hotmail.com

Ana Regina de Oliveira Moreira

ORCID: https://orcid.org/0000-0003-3756-2675

Federal University of Alagoas, Brazil

E mail: ana.regina@foufal.ufal.br

Isabel Cristina Celerino de Moraes Porto

ORCID: https://orcid.org/0000-0003-0908-7424

Federal University of Alagoas, Brazil

E mail: sabelcmporto@gmail.com

Fernando José Camello de Lima

ORCID: https://orcid.org/0000-0003-1593-7747

Federal University of Alagoas, Brazil

E mail: fernando.camello@hotmail.com

Dayse Andrade Romão

ORCID: https://orcid.org/0000-0002-7884-1657

Federal University of Alagoas, Brazil

E mail: dayseromao@gmail.com

Valdeci Elias dos Santos Junior

ORCID: https://orcid.org/0000-0001-9748-5830

Federal University of Alagoas, Brazil

E mail: valdeciodonto@gmail.com

\begin{abstract}
The present study analyzed the neonatal outcomes reported in pregnant women with COVID-19. An integrative review was carried out after formulating the guiding question. That done, the research strategy, selection of criteria and data extraction were carried out. The searches were performed in the databases "PubMed", "Web of Science", "LILACS" and "ScienceDirect" using the following search terms: 2019-nCoV, covid-19, SARS-CoV-2, pregnant, pregnancy, birth, fetal, neonatal, outcomes, complications and adverse. The studies involved 226 pregnant women diagnosed with COVID-19 and 174 healthy pregnant women. Among the 226 pregnant women with COVID-19, there was 01 intrauterine fetal death and 16 remained pregnant until the end of the respective studies. Thus, 209 pregnant women with COVID-19 evolved for childbirth, resulting in 212 live births. Of these, $127(59.9 \%)$ were born by cesarean delivery, $38(17.9 \%)$ were born at $<37$ weeks of gestational age [3 (1.4\%) <28 weeks] and $16(7.5)$ were born at weight $<2500 \mathrm{~g}$. Neonatal results included $8(3.8 \%)$ with a positive SARS-CoV-2 test, $12(5.7 \%)$ with fetal distress, neonatal asphyxia, vomiting or skin rashes, $2(0.9 \%)$ with intravascular coagulation disseminated, $1(0.5 \%)$ alteration of cardiac enzymes, $1(0.5 \%)$ multiple organ failure and $1(0.5 \%)$ neonatal death. Various complications have been identified in pregnant women with COVID-19, therefore, a greater care must be given to this population group due to a greater risk of neonatal complications.
\end{abstract}


Keywords: Covid-19; SARS-CoV-2; Pregnant; Neonatal results.

\section{Resumo}

O presente estudo analisou os desfechos neonatais relatados em mulheres grávidas com COVID-19. Uma revisão integrativa foi realizada após a formulação da questão norteadora. Feito isso, procedeu-se a estratégia de pesquisa, a seleção dos critérios e a extração dos dados. As buscas foram realizadas nas bases de dados "PubMed", "Web of Science", "LILACS" e "ScienceDirect" utilizando os seguintes termos de busca: 2019-nCoV, covid-19, SARS-CoV2, gravidez, gestação, nascimento, fetal, neonatal, resultados, complicações e adversos. Os estudos envolveram 226 gestantes com diagnóstico de COVID-19 e 174 gestantes saudáveis. Entre as 226 gestantes com COVID-19, houve 01 óbito fetal intrauterino e 16 permaneceram grávidas até o final dos respectivos estudos. Assim, 209 gestantes com COVID-19 evoluíram para o parto, resultando em 212 nascidos vivos. Destas, $127(59,9 \%)$ nasceram de parto cesáreo, $38(17,9 \%)$ nasceram com <37 semanas de idade gestacional [3 (1,4\%) <28 semanas] e $16(7,5)$ nasceram com peso <2500 g. Os resultados neonatais incluíram 8 (3,8\%) com um teste SARS-CoV-2 positivo, 12 (5,7\%) com sofrimento fetal, asfixia neonatal, vômitos ou erupções cutâneas, $2(0,9 \%)$ com coagulação intravascular disseminada, $1(0,5 \%)$ alteração de enzimas cardíacas, $1(0,5 \%)$ falência de múltiplos órgãos e $1(0,5 \%)$ óbito neonatal. Complicações variadas foram identificadas em gestantes com COVID-19, logo, um maior cuidado deve ser prestado a esse grupo populacional devido à um maior risco de complicações neonatais.

Palavras-chave: Covid-19; SARS-CoV-2; Gestação; Resultados neonatais.

\section{Resumen}

El presente estudio analizó los resultados neonatales informados en mujeres embarazadas con COVID-19. Se realizó una revisión integradora luego de formular la pregunta orientadora. Hecho esto, se llevó a cabo la estrategia de investigación, selección de criterios y extracción de datos. Las búsquedas se realizaron en las bases de datos "PubMed", "Web of Science", "LILACS" y "ScienceDirect" utilizando los siguientes términos de búsqueda: 2019nCoV, covid-19, SARS-CoV-2, embarazo, embarazada, parto, fetal, neonatal, resultados, complicaciones y adversas. Los estudios involucraron a 226 mujeres embarazadas diagnosticadas con COVID-19 y 174 mujeres embarazadas sanas. Entre las 226 mujeres embarazadas con COVID-19, hubo 01 muerte fetal intrauterina y 16 permanecieron embarazadas hasta el final de los estudios respectivos. Por lo tanto, 209 mujeres embarazadas con COVID-19 evolucionaron para el parto, lo que resultó en 212 nacidos vivos. De estos, $127(59,9 \%)$ nacieron por cesárea, 38 $(17,9 \%)$ nacieron con $<37$ semanas de edad gestacional $[3(1,4 \%)<28$ semanas] y $16(7,5)$ nacieron en peso $<2500 \mathrm{~g}$. Los resultados neonatales incluyeron $8(3,8 \%)$ con una prueba de SARS-CoV-2 positiva, $12(5,7 \%)$ con sufrimiento fetal, asfixia neonatal, vómitos o erupciones cutáneas, $2(0,9 \%)$ con coagulación intravascular diseminada, $1(0,5 \%)$ alteración de las enzimas cardíacas, $1(0,5 \%)$ insuficiencia multiorgánica y $1(0,5 \%)$ muerte neonatal. Se han identificado diversas complicaciones en gestantes con COVID-19, por lo que se debe brindar una mayor atención a este grupo de población debido a un mayor riesgo de complicaciones neonatales.

Palabras clave: Covid-19; SARS-CoV-2; Embarazada; Resultados neonatales.

\section{Introduction}

Coronavirus 2019 (COVID-19), responsible for the outbreak of severe acute respiratory syndrome coronavirus 2 (SARS-CoV-2) (Ludvigsson, 2020) and the current pandemic, is one of seven species of coronavirus that infect humans and is among the three that are potentially fatal (Zhou et al., 2020; Lu et al., 2020). The outbreak was considered to have started in Wuhan, China, and the World Health Organization declared the pandemic and a Public Health Emergency of International Importance on January 30, 2020 (Li et al., 2020; Baloch et al., 2020). As of May 29, 2020, 5.701.337 cases of COVID-19 and 357.688 deaths were recorded (Baloch et al., 2020).

Injuries caused by this disease, through imbalance in the immune system, hydroelectrolytic disorders and systemic inflammatory response, can promote tissue damage and impairment of the lung and other organs, as has been observed in the evolution of severe cases to acute renal failure, acute myocardial injury and/or acute myocardial infarction (Bansal, 2020; Lippi \& Plebani, 2020). In Wuhan, 94\% of fatal patients died from multiple organ failure (Du et al., 2020).

There is still a scarcity of studies on this infection in pregnant women but those already performed have found changes similar to those in non-pregnant adults: immune disorders, systemic inflammation and pulmonary involvement (Wang et al., 2020; Chen et al., 2020). Therefore, the aim of this study is to review neonatal outcomes reported for pregnant women with COVID-19. 


\section{Methodology}

This integrative review was carried out following the formulation of the guiding question, the research strategy, the selection of criteria and data extraction (Whittemore \& Knafl, 2005). The guiding question was developed according to the PICO model (Population, Intervention, Comparison, Result) (Schardt et al., 2007), which improves the formulation of the guiding question and the location of relevant studies.

\subsection{Search strategy and selection of studies}

The searches were performed March 17 - September 28, 2020, in the databases "PubMed", "Web of Science", "LILACS" and "ScienceDirect" using the following search terms: 2019-nCoV, covid-19, SARS-CoV-2, pregnancy, pregnant, born, fetal, neonatal, perinatal outcomes, complication and adverse. No language filters were used and all results were analyzed for title, abstract and full text.

The studies included and reviewed reported obstetric complications and neonatal outcomes for pregnant women with COVID-19 diagnosed using real-time quantitative polymerase chain reaction (qRT-PCR), polymerase chain reaction (PCR) or clinical diagnosis using computed tomography and clinical findings compatible with COVID-19. Studies with undescribed neonatal outcomes were excluded, as well as duplicate studies and those with pregnant women with congenital diseases.

\subsection{Data extraction}

Data were independently extracted by three researchers: type of study, sample size, average sample age, gestational age (weeks (w) and days (d)), severity of COVID-19 disease, prevalence/incidence of comorbidities and adverse neonatal outcomes. Any disagreement, such as study type, duplicity, case of genetic disease, was resolved by consensus.

\section{Results}

\subsection{Selection of studies}

The search in the databases resulted in 427 articles. After exclusion due to duplication, selection by title, by summary, availability and selection by full text, 14 articles with 226 pregnant women with COVID-19 and 174 healthy pregnant women were included in this review. Until the writing of this article was completed (May 28, 2020), new searches, new searches were carried out in the databases for possible new studies to include; no new studies were published and included.

Maternal data and neonatal outcomes from the included studies (were extracted and are available in Table 1. The published studies are of varied methodologies, promoting heterogeneity. Of the 14 studies included, 3 were case reports, 2 were case control studies, 2 were prospective studies and 7 were retrospective studies. Data on the severity of COVID-19 was not discussed in all articles, but some categorized it into mild, moderate, severe or critical symptoms. 
Table 1 - General characteristics of the studies included of pregnant women with COVID-19 including neonatal outcomes.

\begin{tabular}{|c|c|c|c|c|}
\hline $\begin{array}{l}\text { Study } \\
\text { reference }\end{array}$ & Type of study & $\begin{array}{c}\text { Sample } \\
\text { MA } \\
\text { GA } \\
\text { N(pregnant women) } \\
\end{array}$ & $\begin{array}{c}\text { Comorbidity } \\
\mathrm{N}(\%)\end{array}$ & $\begin{array}{c}\text { Delivery } \\
\text { Adverse neonatal outcome } \\
\mathrm{N}(\% \text { of neonates })\end{array}$ \\
\hline $\begin{array}{l}\text { Lieu et al., } \\
2020 .\end{array}$ & Case control & $\begin{array}{l}N \text { case group } \\
N=16 \text { confirmed } \\
N=18 \text { suspected } \\
26-37 \text { years-old } \\
38 w \\
N \text { control group } \\
N=121 \\
25-35 \text { years-old } \\
32-39 \text { w7d }\end{array}$ & $\begin{array}{l}\text { case group: } \\
\text { confirmed group: gestational } \\
\text { diabetes mellitus } 3(18.7 \%) \\
\text { premature rupture of membranes } \\
1(6.2 \%) \\
\text { gestational hypertension } 3(18.7 \%) \\
\text { hypothyroidism } 2(12.5 \%) \\
\text { preeclampsia } 1(6.2 \%) \\
\text { sinus tachycardia } 1(6.2 \%) \\
\text { suspected group: preeclampsia } \\
1(5.6 \%) \text { placenta previa } 1(5.6 \%) \\
\text { control group: } \\
\text { comorbities not informed }\end{array}$ & $\begin{array}{l}\text { case group: } \\
\mathrm{N}=36(100 \%) \\
\text { cesarean section } 32(88.9 \%) \\
2 \text { sets of twins, } 1 \text { in the confirmed } \\
\text { group and } 1 \text { in the suspected group } \\
\text { confirmed group: } \\
\mathrm{N}=17(100 \%) \\
\text { prematurity } 4(23.5 \%) \\
\text { low birth weight } 3(17.6 \%) \\
\text { intrauterine fetal distress } 2(11.8 \%) \\
\text { suspected group } \quad(18 \text { neonates } \\
\text { (100\%): } \\
\mathrm{N}=19(100 \%) \\
\text { prematurity } 4(21.1 \%) \\
\text { low birth weight } 2(10.5 \%) ; \\
\text { intrauterine fetal distress } 1(5.3 \%) \\
\text { control group: } \\
\mathrm{N}=121(100 \%) \\
\text { cesarean section } 50(41.3 \%) \\
\text { prematurity } 7(5.8 \%) \\
\text { low birth weight } 3(2.5 \%) \\
\text { intrauterine fetal distress } 6(4.9 \%)\end{array}$ \\
\hline
\end{tabular}

\begin{tabular}{|c|c|c|}
\hline $\begin{array}{l}\text { Chen et Retrospective } \\
\text { al., 2020. }\end{array}$ & $\begin{array}{l}\mathrm{N}=9 \\
26-40 \text { years-old } \\
36 \mathrm{w}-39 \mathrm{w} 4 \mathrm{~d}\end{array}$ & $\begin{array}{l}\text { gestational hypertension } 1(11.1 \%) \\
\text { preeclampsia } 1(11.1 \%) \\
\text { influenza virus } 1(11.1 \%)\end{array}$ \\
\hline
\end{tabular}

$\begin{array}{ll}\text { Wang et } \quad \text { Case report } & \mathrm{N}=1 \\ \text { al., 2020. } & \\ & 34 \text { years-old } \\ & 40 \mathrm{w}\end{array}$

Zeng et Retrospective $\mathrm{N}=3$

al., 2020 . age not informed

$31 w 2 d-40 w 4 d$

$\mathrm{Hu}$ et al., Retrospective $\mathrm{N}=7$

$\begin{array}{ll}2020 . & 30-34 \text { years-old } \\ & 37 \mathrm{w}-41 \mathrm{w} 2 \mathrm{~d}\end{array}$ influenza virus $1(11.1 \%)$

$\mathrm{N}=9(100 \%)$

cesarean section $9(100 \%)$

prematurity $4(44.4 \%)$

low birth weight $4(44.4 \%)$

serum elevation of myocardial

enzymes $1(11.1 \%)$

hypothyroidism $1(100 \%)$

history of chromosomal alteration

$1(100 \%)$;

severe COVID-19

$\mathrm{N}=1(100 \%)$

cesarean section $1(100 \%)$

positive test for SARS-CoV-2

$1(100 \%)$

no comorbidity informed

$\mathrm{N}=3(100 \%)$

cesarean sections $3(100 \%)$

prematurity $1(33.3 \%)$

low birth weight $1(33.3 \%)$

neonatal asphyxia $1(33.3 \%)$

positive test for SARS-CoV-2

$3(100 \%)$

liver dysfunction $1(14.3 \%)$

$\mathrm{N}=7(100 \%)$

vaginal delivery $7(100 \%)$

positive test for SARS-CoV-2

$1(14.3 \%)$ 
Research, Society and Development, v. 10, n. 1, e0510110905, 2021

(CC BY 4.0) | ISSN 2525-3409 | DOI: http://dx.doi.org/10.33448/rsd-v10i1.10905

$\begin{array}{lll}\text { Ferrazzi et } & \text { Retrospective } & \mathrm{N}=42 \\ \text { al., 2020. } & 21-44 \\ & 30>37 \mathrm{w} \\ & 7=34-37 \mathrm{w} ; \\ & 4 \leq 34 \mathrm{w}\end{array}$

$\begin{array}{lll}\text { Zhu et } & \text { Prospective } & \mathrm{N}=9 \\ \text { al., } & & 25-35 \text { years-old } \\ 2020 . & & 31-39 \mathrm{w}\end{array}$

Symptomatic

group:

$\mathrm{N}=46$

25 - 33 years-old

43 in the third

trimester - not

detailed

+1 fetal death at

$17 \mathrm{w}$

+1 at $25 \mathrm{w}$

+1 at $26 \mathrm{w}$

Asymptomatic

group:

$\mathrm{N}=22$

$24-34$ years-old

All in the third

trimester of

pregnancy - not

detailed

$\begin{array}{lll}\text { Peng et } & \text { Case report } & \mathrm{N}=1 \\ \text { al., } & & 25 \text { years-old } \\ 2020 & & 35 \mathrm{w} 3 \mathrm{~d}\end{array}$

$\begin{array}{lll}\begin{array}{l}\text { Liao } \\ \text { al., }\end{array} & \begin{array}{l}\text { Case } \\ \text { control }\end{array} & \begin{array}{l}\text { N case group }=10 \\ 27-36 \text { years-old } \\ 2020\end{array} \\ & & 36 w 2 d-40 w 2 d \\ & \\ & & \text { N control group }=53 \\ & & \\ & & 31-37 \text { years old } \\ & & \end{array}$

gestational diabetes 6(85.7\%).

no comorbidity informed

Symptomatic group:

preeclampsia $2(6.1 \%)$

other comorbidity (in the $\mathrm{N}$ total)

$15(32.6 \%)$ - not described

Asymptomatic group:

preeclampsia $1(4.5 \%)$

other comorbidity (in the $\mathrm{N}$ total)

$4(18.2 \%)$ - not described

\section{$\mathrm{N}=42(100 \%)$}

cesarean section $18(42.8 \%)$

prematurity $11(26.2 \%)$

positive test for SARS-CoV-2

$3(7.1 \%)$

$\mathrm{N}=10$

cesarean sections $6(60 \%)$

low weight at birth $6(60 \%)$

pediatric critical illness score $6(60 \%)$

disseminated intravascular

coagulation $2(20 \%)$

multiple organ failure $1(10 \%)$

death neonatal $1(10 \%)$

respiratory distress, vomiting or skin rashes $7(90 \%)$

1 case of twin pregnancy

Symptomatic group:

12 pregnancies were ongoing at study end

01 fetal death at 17 weeks

$\mathrm{N}=33(100 \%)$

cesarean section $16(48.5 \%)$

prematurity $12(36.4 \%)$

Asymptomatic group:

$\mathrm{N}=22(100 \%)$

cesarean section $6(27.3 \%)$ no comorbidity

Case group

no comorbidity informed

mild respiratory symptoms $10(100 \%)$

Control group

no comorbidity informed

$\mathrm{N}=1(100 \%)$

cesarean section $1(100 \%)$

prematurity $1(100 \%)$

intrauterine fetal distress $1(100 \%)$

$\mathrm{N}=63(100 \%)$

vaginal delivery $63(100 \%)$

Case group:

$\mathrm{N}=10(100 \%)$

premature $1(10 \%)$

Control group:

$\mathrm{N}=53(100 \%)$

prematurity $5(9.4 \%)$

neonatal asphyxia $4(7.5 \%)$

$\mathrm{N}=7(100 \%)$

hypothyroidism 1(14.3\%)

polycystic ovary syndrome

$1(14.3 \%)$
29 - 34 years-old

$37-41 \mathrm{w}$

2020.

$\begin{array}{ll}\text { Retrospecti } & \mathrm{N}=7 \\ \text { ve } & 29-34 \text { years-old } \\ & 37-41 \mathrm{w}\end{array}$




\begin{tabular}{|c|c|c|c|c|}
\hline $\begin{array}{l}\text { Liu W } \\
\text { et al., } \\
2020 \text {. }\end{array}$ & Prospective & $\begin{array}{l}\mathrm{N}=19 \\
27-34 \text { years-old } \\
38 w 6 \mathrm{~d} \\
\text { (average reported) }\end{array}$ & no comorbidity informed & $\begin{array}{l}\mathrm{N}=19(100 \%) \\
\text { cesarean sections } 18(94.7 \%)\end{array}$ \\
\hline
\end{tabular}

$\begin{array}{lll}\text { Liu D et } & \text { Retrospecti } & \mathrm{N}=15 \\ \text { al., } & \text { ve } & 23-40 \text { years-old } \\ 2020 . & & 12-38 \mathrm{w}\end{array}$

$\begin{array}{ll}\text { thalassemia and gestational } & 4 \text { pregnancies were ongoing at } \\ \text { diabetes mellitus } 1(6.7 \%) & \text { study end } \\ \text { replacement of mitral and } & \mathrm{N}=11(100 \%) \\ \text { tricuspid valves } 1(6.7 \%) & \text { cesarean section } 10(90.9 \%)\end{array}$
placenta previa $1(6.7 \%)$.

\begin{tabular}{|c|c|c|c|c|}
\hline $\begin{array}{l}\text { Xiong } \\
\text { et al., } \\
2020 \text {. }\end{array}$ & Case report & $\begin{array}{l}\mathrm{N}=1 \\
25 \text { years-old } \\
38 \mathrm{w} 4 \mathrm{~d}\end{array}$ & no comorbidity & $\begin{array}{l}\mathrm{N}=1(100 \%) \\
\text { vaginal delivery } 1(100 \%)\end{array}$ \\
\hline
\end{tabular}

$\mathrm{MA}=$ maternal age at time of study; GA: gestational age at time of study ( $w=$ week; $d=$ day); $N=$ number of participants; Source: Authors.

The 226 pregnant women with COVID-19 included 18 from one study (Li et al., 2020) with suspected infection based on signs, symptoms and changes in chest CT scan characteristic of COVID-19 and negative laboratory tests. According to the authors of that study ( $\mathrm{Li}$ et al., 2020), cases of false negatives may be common for cases of COVID-19 infection due to due to virulence, advanced disease sampling and inappropriate swabbing sites.

\subsection{Characteristics and comorbidities of pregnant women with COVID-19}

Among maternal characteristics at time of study, the age of the pregnant women ranged from 21 to 44 years-old and the gestational age ranged from 12 to 42 weeks. Three pregnant women with COVID-19 had twin pregnancies (Li et al., 2020; Zhu et al., 2020). In addition, of the 226 pregnant women, 01 had an intrauterine fetal death at 17 weeks of gestation and 16 were still pregnant at the end of the study. Therefore, 209 pregnant women and their neonatal outcomes were described.

The presence or absence of comorbidity of 185 pregnant women was reported. Of these, 51 (27.6\%) had pre-existing comorbidities or diseases during pregnancy (gestational diabetes mellitus, pre-eclampsia, placenta previa, influenza virus). Severe symptoms were reported in only one study of a 34-year-old woman, 40 weeks of gestation, and a clinical history of hypothyroidism and obstetric chromosomal alteration (Wang et al., 2020). The other studies followed with reports of mild, moderate or unreported respiratory symptoms (Li et al., 2020; Chen et al., 2020; Zeng et al., 2020; Hu et al., 2020; Ferrazzi et al., 2020; Zhu et al., 2020; London et al., 2020; Peng et al., 2020; Liao et al., 2020; Yu et al., 2020; Liu et al., 2020; Liu et al., 2020; Xiong et al., 2020). Among pregnant women without COVID-19, there was no report of pre-existing comorbidity or gestational disease.

\subsection{Neonatal outcomes}

Neonatal outcomes were reported for 212 infants born to 209 women with COVID-19 (confirmed and suspected), including 3 sets of twins in two studies (Li et al., 2020; Zhu et al., 2020). Of these 127 (59.9\%) were delivered by cesarean section and $85(40.1 \%)$ vaginally. Thirty-eight (17.9\%) were born <37 gestational weeks [3 (1.4\%) were born extremely premature at $<28$ gestational weeks], and $16(7.5 \%)$ were born with low birth weight $(<2500 \mathrm{~g})$.

Neonatal complications were reported in 10, included fetal distress, neonatal asphyxia, vomiting or skin rashes ( $\mathrm{n}=12$ [5.7\%]), alteration of cardiac enzymes $(n=1[0.5 \%])$, positive test for SARS-CoV-2 $(n=8[3.8 \%])$, disseminated intravascular 
coagulation $(n=2[0.9 \%])$, multiple organ failure $(n=1[0.5 \%])$ and death $(n=1[0.5 \%])$. No maternal or fetal complications or adverse neonatal outcomes were reported in 4 studies (Yu et al., 2020; Liu et al., 2020; Liu et al., 2020; Xiong et al., 2020 ).

Newborns with a positive test for SARS-CoV-2 were reported in 04 studies [13-16] and all survived until the end of the respective study. One case was related in a case report (34-year-old pregnant woman, 40 gestational weeks, hypothyroidism, chromosomal alteration in a previous pregnancy and severity of COVID-19), where a newborn was diagnosed with SARS-CoV-2 through a test performed after birth and evolved without complications until hospital discharge (Wang et al., 2020).

The remaining $(\mathrm{n}=7)$ newborns positive for SARS-CoV-2 have been reported in three other studies (Zeng et al, 2020; Hu et al., 2020; Ferrazzi et al., 2020). Of these, 06 were born by cesarean section (Zeng et al, 2020; Ferrazzi et al., 2020) and 01 were born by vaginal delivery ( $\mathrm{Hu}$ et al., 2020), 06 were born at term (Hu et al., 2020; Ferrazzi et al., 2020) and 01 was premature (31 weeks (w) and 2 days (d)), had low birth weight (1580g), had asphyxia and received mechanical ventilation (Zeng et al, 2020). According to the authors, two of these cases were positive after the newborn had contact (be breastfed) (Ferrazzi et al., 2020).

It is important to consider that, except for the case reported in the previous paragraph, the other records of disseminated intravascular coagulation, organ dysfunction, neonatal death, alteration of cardiac enzymes, fetal distress, neonatal asphyxia, vomiting or skin rashes were not in newborns diagnosed with COVID-19 (liu et al., 2020; Chen et al., 2020; Zeeng et al., 2020; Zhu et al., 2020; Peng et al., 2020; Liao et al., 2020).

Three studies analyzed neonatal outcomes according to the presence or absence of symptoms of COVID-19 (London et al., 2020), with or without the diagnosis of COVID-19 [20] or with laboratory or suspected diagnosis (Liu et al., 2020). In the comparison between symptomatic and asymptomatic pregnant women, the prevalence of outcomes was among symptomatic women with $16(48.5 \%)$ cases of cesarean birth vs $6(27.3 \%), 12(36.4 \%)$ cases of prematurity vs 0 . The one fetal death occurred in a symptomatic woman (London et al., 2020).

In a study of 10 pregnant women with COVID-19 and mild respiratory symptoms and 53 pregnant women without COVID-19, all infants were born by vaginal delivery and the proportion born prematurely was similar (10.0\% of the cases and $9.4 \%$ of the controls). Four (7.5\%) infants in the control group had neonatal asphyxia (Liao et al., 2020). Another study compared outcomes among pregnant women who had laboratory confirmed COVID-19, women with suspected COVID-19 clinically diagnosed, and women without COVID-19 (Liu et al., 2020). Adverse outcomes were reported with similar frequency in the neonates born to women with confirmed and suspected COVID-19, including prematurity (23.5\% vs $21.1 \%)$, low birth weight (17.6\% vs $10.5 \%)$, and intrauterine fetal distress (11.8\% vs 5.3\%). However, the proportions of neonates born preterm and with low birth weight were higher than among infants born to non-infected women.

\section{Discussion}

In this review, $8(3.8 \%)$ of 212 live newborns from women diagnosed with COVID-19 tested positive for COVID-19. Two had unprotected contact with their mothers while the remaining six had been kept isolated. Other adverse neonatal outcomes were reported including prematurity, low birth weight, multiple organ failure and death.

There is a need for more information about COVID-19 during pregnancy, but studies have shown changes similar to those reported in non-pregnant women (Chen et al., 2020; Zhao et al., 2020): immune disorders, hyperinflammation (“"called cytokine storm”) and damage endothelial (Guzik et al., 2020; Bairey Merz et al., 2020; Monteil et al., 2020). Laboratory data record changes in the count of white blood cells, lymphocytes, neutrophils and platelets, in addition to a significant increase in the serum concentration of inflammatory biomarkers, such as ferritin, C-reactive protein (CRP), interleukin (IL)-6, IL-8, IL10). Markers of impairment of other organs related to the severity of the disease, such as kidneys, heart and liver, were 
identified through changes in the serum level of creatinine, albumin, blood urea nitrogen, creatinine kinase, myoglobin, aspartate aminotransferase (AST) and ALT (alanine aminotransferase) (Henry et al., 2020).

In other inflammatory diseases that arise during pregnancy, there is a significant increase in adverse neonatal outcomes, such as prematurity, low birth weight and restricted intrauterine growth (Skrablin et al., 2007). These adverse outcomes, in turn, are associated with a higher risk of neonatal complications, a longer hospital stay, a higher risk of sequelae and mortality (Leung et al., 2018; Cardoso-Demartini et al., 2011; Maggi et al., 2014). In this study, 08 cases of neonates with COVID-19 were reported, in addition to serious complications (neonatal asphyxia, multiple organ failure and death).

As shown in Table 1, although not all studies reported details, information about the presence of comorbidity was described for 185 pregnant women and 51 (27.6\%) had it. In a study of 46 pregnant women with COVID-19 (Lokken et al., 2020), disease severity and worse neonatal outcomes were associated with the presence of pre-existing comorbidity combined with overweight or obesity. It is important to consider the presence of comorbidity as a risk factor for pregnant women with COVID-19, since it can cause a sum of changes and complications that directly affect fetal development and the progress of pregnancy, and is already associated to worse neonatal outcomes (Guedes et al., 2020).

\section{Final Considerations}

This review identified the main neonatal outcomes of pregnant women diagnosed with COVID. This disease is not yet fully understood and, therefore, poses numerous challenges for the health system. The published data, until then, are of varied methodologies and results, as well as the outcomes found. Various complications have been identified in pregnant women with COVID-19, therefore, a greater care must be given to this population group due to a greater risk of neonatal complications.

\section{References}

Bairey Merz, C. N., Pepine, C. J., Shimokawa, H., \& Berry, C. (2020). Treatment of coronary microvascular dysfunction. Cardiovascular research, 116(4), 856-870. https://doi.org/10.1093/cvr/cvaa006.

Bansal, M. (2020). Cardiovascular disease and COVID-19. Diabetes \& metabolic syndrome, 14(3), 247-250. https://doi.org/10.1016/j.d sx.2020.03.013.

Baloch, S., Baloch, M. A., Zheng, T., \& Pei, X. (2020). The Coronavirus Disease 2019 (COVID-19) Pandemic. The Tohoku journal of experimental medicine, 250(4), 271-278. https://doi.org/10.1620/tjem.250.271.

Cardoso-Demartini, A., Bagatin, A. C., Silva, R. P., \& Boguszewski, M. C. (2011). Crescimento de crianças nascidas prematuras [Growth of preterm-born children]. Arquivos brasileiros de endocrinologia e metabologia, 55(8), 534-540. https://doi.org/10.1590/s0004-2730201 1000800006 .

Chen, H., Guo, J., Wang, C., Luo, F., Yu, X., Zhang, W., Li, J., Zhao, D., Xu, D., Gong, Q., Liao, J., Yang, H., Hou, W., \& Zhang, Y. (2020). Clinical characteristics and intrauterine vertical transmission potential of COVID-19 infection in nine pregnant women: a retrospective review of medical records. Lancet (London, England), 395(10226), 809-815. https://doi.org/10.1016/S0140-6736(20)30360-3 .

Du, Y., Tu, L., Zhu, P., Mu, M., Wang, R., Yang, P., Wang, X., Hu, C., Ping, R., Hu, P., Li, T., Cao, F., Chang, C., Hu, Q., Jin, Y., \& Xu, G. (2020). Clinical Features of 85 Fatal Cases of COVID-19 from Wuhan. A Retrospective Observational Study. American journal of respiratory and critical care medicine, 201(11), 1372-1379. https://doi.org/10.1164/rccm.202003-0543OC .

Ferrazzi, E., Frigerio, L., Savasi, V., Vergani, P., Prefumo, F., Barresi, S., Bianchi, S., Ciriello, E., Facchinetti, F., Gervasi, M. T., Iurlaro, E., Kustermann, A., Mangili, G., Mosca, F., Patanè, L., Spazzini, D., Spinillo, A., Trojano, G., Vignali, M., Villa, A., Cetin, I. (2020). Vaginal delivery in SARS-CoV-2-infected pregnant women in Northern Italy: a retrospective analysis. BJOG: an international journal of obstetrics and gynaecology, 127(9), 1116-1121. https://doi.org/10.1111/1471-0528.16278 . 
Guedes, B. L. C. dos S., Nascimento, A. K. P. do, Melo, B. T. G., Cunha, S. M. D., Oliveira Filho, A. A. de., \& Oliveira, H. M. B. F. de. (2020). General aspects of COVID-19 in pregnant and newborn health: A brief review. Research, Society and Development, 9(7), e897974969. https://doi.org/10.33448/rsdv9i7.4969.

Guzik, T. J., Mohiddin, S. A., Dimarco, A., Patel, V., Savvatis, K., Marelli-Berg, F. M., Madhur, M. S., Tomaszewski, M., Maffia, P., D'Acquisto, F., Nicklin, S. A., Marian, A. J., Nosalski, R., Murray, E. C., Guzik, B., Berry, C., Touyz, R. M., Kreutz, R., Wang, D. W., Bhella, D., McInnes, I. B. (2020). COVID-19 and the cardiovascular system: implications for risk assessment, diagnosis, and treatment options. Cardiovascular research, 116(10), 1666-1687. https://doi.org/10.1093/cvr/cvaa106.

Henry, B. M., de Oliveira, M., Benoit, S., Plebani, M., \& Lippi, G. (2020). Hematologic, biochemical and immune biomarker abnormalities associated with severe illness and mortality in coronavirus disease 2019 (COVID-19): a meta-analysis. Clinical chemistry and laboratory medicine, 58(7), 1021-1028. https://doi.org/10.1515/cclm-2020-0369.

Hu, X., Gao, J., Luo, X., Feng, L., Liu, W., Chen, J., Benachi, A., De Luca, D., \& Chen, L. (2020). Severe Acute Respiratory Syndrome Coronavirus 2 (SARS-CoV-2) Vertical Transmission in Neonates Born to Mothers With Coronavirus Disease 2019 (COVID-19) Pneumonia. Obstetrics and gynecology, 136(1), 65-67. https://doi.org/10.1097/AOG.0000000000003926.

Leung, M. P., Thompson, B., Black, J., Dai, S., \& Alsweiler, J. M. (2018). The effects of preterm birth on visual development. Clinical \& experimental optometry, 101(1), 4-12. https://doi.org/10.1111/cxo.12578.

Li, N., Han, L., Peng, M., Lv, Y., Ouyang, Y., Liu, K., Yue, L., Li, Q., Sun, G., Chen, L., \& Yang, L. (2020). Maternal and Neonatal Outcomes of Pregnant Women With Coronavirus Disease 2019 (COVID-19) Pneumonia: A Case-Control Study. Clinical infectious diseases : an official publication of the Infectious Diseases Society of America, 71(16), 2035-2041. https://doi.org/10.1093/cid/ciaa352.

Liao, J., He, X., Gong, Q., Yang, L., Zhou, C., \& Li, J. (2020). Analysis of vaginal delivery outcomes among pregnant women in Wuhan, China during the COVID-19 pandemic. International journal of gynaecology and obstetrics: the official organ of the International Federation of Gynaecology and Obstetrics, 150(1), 53-57. https://doi.org/10.1002/ijgo.13188.

Liu, D., Li, L., Wu, X., Zheng, D., Wang, J., Yang, L., \& Zheng, C. (2020). Pregnancy and Perinatal Outcomes of Women With Coronavirus Disease (COVID-19) Pneumonia: A Preliminary Analysis. AJR. American journal of roentgenology, 215(1), 127-132. https://doi.org/10.2214/AJR.20.23072.

Liu, W., Wang, J., Li, W., Zhou, Z., Liu, S., \& Rong, Z. (2020). Clinical characteristics of 19 neonates born to mothers with COVID-19. Frontiers of medicine, 14(2), 193-198. https://doi.org/10.1007/s11684-020-0772-y.

Lippi, G., \& Plebani, M. (2020). Laboratory abnormalities in patients with COVID-2019 infection. Clinical chemistry and laboratory medicine, 58(7), 11311134. https://doi.org/10.1515/cclm-2020-0198.

Lokken, E. M., Walker, C. L., Delaney, S., Kachikis, A., Kretzer, N. M., Erickson, A., Resnick, R., Vanderhoeven, J., Hwang, J. K., Barnhart, N., Rah, J., McCartney, S. A., Ma, K. K., Huebner, E. M., Thomas, C., Sheng, J. S., Paek, B. W., Retzlaff, K., Kline, C. R., Munson, J., ... Adams Waldorf, K. M. (2020). Clinical characteristics of 46 pregnant women with a severe acute respiratory syndrome coronavirus 2 infection in Washington State. American journal of obstetrics and gynecology, 223(6), 911.e1-911.e14. https://doi.org/10.1016/j.ajog.2020.05.031.

London, V., McLaren, R., Jr, Atallah, F., Cepeda, C., McCalla, S., Fisher, N., Stein, J. L., Haberman, S., \& Minkoff, H. (2020). The Relationship between Status at Presentation and Outcomes among Pregnant Women with COVID-19. American journal of perinatology, 37(10), 991-994. https://doi.org/10.1055/s0040-1712164.

Lu, R., Zhao, X., Li, J., Niu, P., Yang, B., Wu, H., Wang, W., Song, H., Huang, B., Zhu, N., Bi, Y., Ma, X., Zhan, F., Wang, L., Hu, T., Zhou, H., Hu, Z., Zhou, W., Zhao, L., Chen, J., Tan, W. (2020). Genomic characterisation and epidemiology of 2019 novel coronavirus: implications for virus origins and receptor binding. Lancet (London, England), 395(10224), 565-574. https://doi.org/10.1016/S0140-6736(20)30251-8. 
Ludvigsson, J. F. (2020). Systematic review of COVID-19 in children shows milder cases and a better prognosis than adults. Acta paediatrica (Oslo, Norway. 1992), 109(6), 1088-1095. https://doi.org/10.1111/apa.15270.

Maggi, E. F., Magalhães, L. C., Campos, A. F., \& Bouzada, M. C. (2014). Preterm children have unfavorable motor, cognitive, and functional performance when compared to term children of preschool age. Jornal de pediatria, 90(4), 377-383. https://doi.org/10.1016/j. jped.2013.10.00533.

Monteil, V., Kwon, H., Prado, P., Hagelkrüys, A., Wimmer, R. A., Stahl, M., Leopoldi, A., Garreta, E., Hurtado Del Pozo, C., Prosper, F., Romero, J. P., Wirnsberger, G., Zhang, H., Slutsky, A. S., Conder, R., Montserrat, N., Mirazimi, A., \& Penninger, J. M. (2020). Inhibition of SARS-CoV-2 Infections in Engineered Human Tissues Using Clinical-Grade Soluble Human ACE2. Cell, 181(4), 905-913.e7. https://doi.org/10.1016/j.cell.2020.04.004.

Peng, Z., Wang, J., Mo, Y., Duan, W., Xiang, G., Yi, M., Bao, L., \& Shi, Y. (2020). Unlikely SARS-CoV-2 vertical transmission from mother to child: A case report. Journal of infection and public health, 13(5), 818-820. https://doi.org/10.1016/j.jiph.2020.04.004.

Schardt, C., Adams, M. B., Owens, T., Keitz, S., \& Fontelo, P. (2007). Utilization of the PICO framework to improve searching PubMed for clinical questions. BMC medical informatics and decision making, 7, 16. https://doi.org/10.1186/1472-6947-7-16.

Skrablin, S., Lovric, H., Banovic, V., Kralik, S., Dijakovic, A., \& Kalafatic, D. (2007). Maternal plasma interleukin-6, interleukin-1beta and C-reactive protein as indicators of tocolysis failure and neonatal outcome after preterm delivery. The journal of maternal-fetal \& neonatal medicine: the official journal of the European Association of Perinatal Medicine, the Federation of Asia and Oceania Perinatal Societies, the International Society of Perinatal Obstetricians, 20(4), 335-341. https://doi.org/10.1080/14767050701227877.

Wang, S., Guo, L., Chen, L., Liu, W., Cao, Y., Zhang, J., \& Feng, L. (2020). A Case Report of Neonatal 2019 Coronavirus Disease in China. Clinical infectious diseases: an official publication of the Infectious Diseases Society of America, 71(15), 853-857. https://doi.org/10.1093/cid/ciaa225.

Wang, F., Nie, J., Wang, H., Zhao, Q., Xiong, Y., Deng, L., Song, S., Ma, Z., Mo, P., \& Zhang, Y. (2020). Characteristics of Peripheral Lymphocyte Subset Alteration in COVID-19 Pneumonia. The Journal of infectious diseases, 221(11), 1762-1769. https://doi.org/10.1093/infdis/jiaa150.

Whittemore, R., \& Knafl, K. (2005). The integrative review: updated methodology. Journal of advanced nursing, 52(5), 546-553. https://doi.org/10.1111/j.1365-2648.2005.03621.x .

Xiong, X., Wei, H., Zhang, Z., Chang, J., Ma, X., Gao, X., Chen, Q., \& Pang, Q. (2020). Vaginal delivery report of a healthy neonate born to a convalescent mother with COVID--19. Journal of medical virology, 92(9), 1657-1659. https://doi.org/10.1002/jmv.25857.

Yu, N., Li, W., Kang, Q., Xiong, Z., Wang, S., Lin, X., Liu, Y., Xiao, J., Liu, H., Deng, D., Chen, S., Zeng, W., Feng, L., \& Wu, J. (2020). Clinical features and obstetric and neonatal outcomes of pregnant patients with COVID-19 in Wuhan, China: a retrospective, single-centre, descriptive study. The Lancet. Infectious diseases, 20(5), 559-564. https://doi.org/10.1016/S1473-3099(20)30176-6.

Zeng, L., Xia, S., Yuan, W., Yan, K., Xiao, F., Shao, J., \& Zhou, W. (2020). Neonatal Early-Onset Infection With SARS-CoV-2 in 33 Neonates Born to Mothers With COVID-19 in Wuhan, China. JAMA pediatrics, 174(7), 722-725. https://doi.org/10.1001/jamapediatrics.2020.0878.

Zhao, X., Jiang, Y., Zhao, Y., Xi, H., Liu, C., Qu, F., \& Feng, X. (2020). Analysis of the susceptibility to COVID-19 in pregnancy and recommendations on potential drug screening. European journal of clinical microbiology \& infectious diseases : official publication of the European Society of Clinical Microbiology, 39(7), 1209-1220. https://doi.org/10.1007/s10096-020-03897-6 .

Zhou, P., Yang, X. L., Wang, X. G., Hu, B., Zhang, L., Zhang, W., Si, H. R., Zhu, Y., Li, B., Huang, C. L., Chen, H. D., Chen, J., Luo, Y., Guo, H., Jiang, R. D., Liu, M. Q., Chen, Y., Shen, X. R., Wang, X., Zheng, X. S., Shi, Z. L. (2020). A pneumonia outbreak associated with a new coronavirus of probable bat origin. Nature, 579(7798), 270-273. https://doi.org/10.1038/s41586-020-2012-7.

Zhu, H., Wang, L., Fang, C., Peng, S., Zhang, L., Chang, G., Xia, S., \& Zhou, W. (2020). Clinical analysis of 10 neonates born to mothers with 2019-nCoV pneumonia. Translational pediatrics, 9(1), 51-60. https://doi.org/10.21037/tp.2020.02.06. 